\title{
Venire contra factum proprium nemini licet - Changing Fortunes of the Maxim Demanding Constancy in Conduct
}

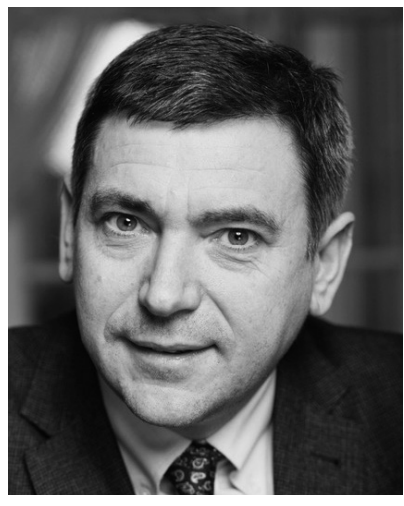

\section{Wojciech Dajczak}

Professor of Law at Adam Mickiewicz University in Poznań; his subjects are Roman law, European legal history, comparative private law; legal methods and math; former judge and legal counsel; he has been an Alexander von Humboldt Fellow; Editor-in-chief of Forum Prawnicze.

$\triangle$ dajczak@amu.edu.pl

https://orcid.org/0000-0002-1565-0319

\author{
Key words: estoppel, legal principles, good faith, European legal \\ tradition \\ https://doi.org/10.32082/fp.v3i53.222
}

\section{Introduction}

The venire contra factum proprium nemini licet legal maxim in legal argumentation expresses objection to inconsistent behaviour. The prohibition on contradicting one's own behaviour, conceived in this maxim, or estoppel in common law countries, constitutes the concept from the Civilian tradition that is renowned for protecting a commitment to loyalty. ${ }^{1}$ An estoppel, says William Blackstone, “...happens where a man hath done some act or excluded some deed which estops or precludes him from averring anything to the contrary." ${ }^{2}$ However, opinions regarding the significance of this maxim are not uniform in discussions among civil law jurists.

1 Cfr. T. L. Sombra, The Duty of Good Faith to a New Level: An Analysis of Disloyal Behaviour, "Journal of Civil Law Studies", 2016, issue 9, p. 29.

2 W. Blackstone, Commentaries on the Laws of England, Book the third, Oxford 1768, p. 308 (III, ch. 20).
The more we look into it, the bigger our embarrassment might be. The maxim's genesis is connected with Roman law ${ }^{3}$ but sources render it possible to connect its origins with legal science in the late Middle Ages. ${ }^{4}$ A picture of those origins which can be relatively easy for us to access is a collection of legal maxims entitled Brocardia sive generalia iuris, whose author is said to be Azo - a jurist who lived at the turn of the $12^{\text {th }}$

3 See H. W. Dette, Venire contra factu proprium nulli conceditur. Zur Konkretisierung eines Rechtssprichtwortes, Berlin 1985, p. 13; R. Singer, Das Verbot wiedersprüchlichen Verhaltens, München 1993, p. 354; P. Mazur, Powolywanie się na nieważność czynności prawnej z naruszeniem zasady venire contra factum proprium niemini licet, "Przegląd Sądowy" 2017, issue 10, p. 57.

4 See E. Riezler, Venire contra factum proprium. Studien im römischen, englischen und deutschen Civilrecht, Leipzig 1912, p. 1. 
and $13^{\text {th }}$ centuries. ${ }^{5}$ Those maxims were formulated mainly on the basis of the sources of ancient Roman law. They were proliferated in our legal tradition thanks to fifteenth-century printed editions. ${ }^{6}$ The divergence between the wide use of the maxim in the pre-codification science and practice of adopted Roman law and the fact that there is no mention of it in nineteenth-century pandectist theory of private law was explained by the aspiration of the latter for fidelity to the Roman sources of law. ${ }^{7}$ A visible increase of the maxim's sig- argumentation in order to achieve "results which are satisfactory in terms of their purpose, when the code does not specify them expressly" (von Fällen teleologisch befriedigende Lösungen gewinnen, die das Gesetz mindestens nicht ausdrücklich vorschreibt). ${ }^{10}$ However, linking the maxim in legal discussions of the $20^{\text {th }}$ and $21^{\text {st }}$ centuries with the good faith clause, combating the abuse of law and protecting legitimate expectations resulted in doubts concerning the correctness of such an argumentative practice. ${ }^{11}$ Research results

\section{Opinions regarding the significance of this maxim} are not uniform in discussions among civil law jurists.

nificance in legal science from the beginning of the $20^{\text {th }}$ century is related to a book by Erwin Riezler dedicated to it. ${ }^{8}$ Azo justified the authority of the maxim and the limits of its application through the texts of ancient Roman law. Riezler indicated it as the source of a number of rules of the German Civil Code. ${ }^{9}$ But, what is more, he indicated the maxim as the expression of an idea which helps to overcome the gaps in codification; an idea which can support ad casum judicial

5 H. Lange, Römisches Recht im Mittelalter, vol. 1, Glossatoren, München 1997, p. 270.

6 Brocardica Azoni sive generalia iuris Azonis Bononiensis, Basileae 1567. I used this edition. For other editions see: Brocardia Aurea Azonis Bononiensis Antiquorum Iurisconsultum in quibus omnes fere iuris antinomiae resolvuntur, Venetiis 1566; Brocardica seu Generalia iuris Azonis Bononiensis Iurisconsultum facile principis, Beuliaqua 1577; Aurea brocardica azonis bononiensis, Venetiis 1581; Aurea Brocardica Azonis Bononiensis Antiquorum Iurisconsultum, Venetiis 1584; Aurea Brocardica Azonis Bononiensi, Summa Azonis: locuples iuris civilis thesaurus, Venetiis 1596; Aurea Brocardica Azonis in quibus omnes fere iuris antinomiae resolventur, Venetiis 1610; Azo (Porcius), Summa Codicis: Institutionum et Digestorum et Brocardica, Frankfurt am Main 2008

7 E. Riezler, Venire..., p. 54.

8 F. Festi, Il divieto di "venire contro il fatto proprio", Milano 2007, p. 32.

9 E. Riezler, Venire..., p. 110-123. which indicate a "definitely smaller than expected"12 argumentative significance of the venire contra factum proprium prohibition do not hinder making an expressive reference to this maxim in supranational attempts to unify the law of contract ${ }^{13}$ or to declare the maxim as one of the basic principles of private law. ${ }^{14}$ Finally, we notice an inconsistency between a thesis stemming from legal history stating that the discussed maxim is a guideline used for orientation rather than an order, ${ }^{15}$ and an assessment that "Polish law does not fully implement the venire contra factum proprium nemini principle" and a related postulate to introduce a norm which renders it possible "in special circumstances" to pursue claims resulting from an invalid legal transaction. ${ }^{16}$

The discussed maxim also gained argumentative significance outside private law with which it is histor-

10 E. Riezler, Venire..., p. 128.

11 H. W. Dette, Venire..., p. 109-110; R. Singer, Das Verbot..., p. 353 .

12 R. Singer, Das Verbot..., p. 352.

13 See F. Festi, Il divieto..., p. 15ff; N. Jansen, R. Zimmermann (eds.), Commentaries on European Contract Law, Oxford 2018, p. 153.

14 P. Mazur, Venire..., p. 58.

15 F. Astone, Venire contra factum proprium, Napoli 2006, p. 74.

16 P. Mazur., Venire..., p. 65. 
ically connected the most. ${ }^{17}$ It is a constituent of European legal tradition. The long history of the maxim is indicated as the source of its contemporary vitality. ${ }^{18}$ Therefore, the embarrassment raised by the outlined inconsistencies draws attention to experience supporting the venire contra factum proprium maxim. It inspires the following questions: Why was the discussed maxim introduced into legal argumentation? Can we notice any systemic elements in using the maxim before it was included - probably by the inspiration of E. Riezler - in the interpretation of the statutory good faith clause? If we can notice elements of a systemic approach in the pre-codification history of the maxim - can they inspire a contemporary view on a useful method of referring to the maxim in private law and if so, how? a relatively easily accessible picture of the first methodological considerations on the binding power of the venire contra factum prorpium nulli conceditur maxim. ${ }^{20}$ Prima facie, they show the fundamental significance of the texts included in the Justinian compilation for such considerations in late-medieval legal science. From among more than fifty fragments treated as ratio scripta and cited to confirm (26 texts) or reject (24 texts) the binding power of the maxim and, finally, as guidelines regarding its validity limits (6 texts), only two did not come from the Justinian compilation. ${ }^{21}$ The formal structure of Isola's paper at its core reproduces the structure of the Brocardia. Explaining the content of the Roman texts cited by Azo to the contemporary reader and the state of dis-

\section{The long history of the maxim is indicated as the source of its contemporary vitality.}

The publication of the very first and extended historical and legal paper on the origins and basics of the venire contra facrum proprium ${ }^{19}$ maxim in 2017 should be received with satisfaction and interest. I take an overview of the method assumed by its Austrian author Lisa Isola and her findings made as the starting point of a search for the answers to the questions asked above.

\section{Lisa Isola's approach to the venire contra} factum proprium maxim in Azo's Brocardia Azo's Brocardia, published in printed form in the $16^{\text {th }}$ century, provides us today with

17 See, e.g. EUECJ C-140/08 (29 October 2009); EUECJ C-177/13P

(13 February 2014); judgement of the Voivodeship Administrative Court in Warsaw IV SA/Wa 551/16 (6 September 2016).

18 W. Dette, Venire..., p. 14; F. Astone, Venire..., p. 2; J. Stelmach, Kodeks argumentacyjny dla prawników, Kraków 2003, p. 86 and 95.

19 L. Isola, Venire contra factum proprium. Herkunft und Grundlagen eines sprichwörtlichen Rechtsprinzips, Frankfurt am Main 2017. cussion regarding them in the contemporary knowledge of ancient Roman law resulted in the fact that three pages in the Brocardia correspond to 384 pages in the mentioned monograph. In this way, the author indicated that medieval jurists had legitimated the maxim using texts from different fields of law. Apart from linking it with the enforceability of contracts, it was confirmed by texts concerning procedural and public law. ${ }^{22}$ Such a presentation of arguments used for the assessment of the maxim also renders it possible to notice the consistency in establishing the limits of the maxim's application between considerations based on Roman texts and those coming from the Decretum Gratiani. ${ }^{23}$ Finally, the texts used in the Brocardia, included in the opposing arguments (contra), render it possible to notice how medieval jurists individualised the values which they used to explain inconsistencies between a purely dogmatic consequence of an act and

\footnotetext{
20 Brocardica..., p. 121-123.

21 These are two fragments of the Decretum Gratiani.

22 L. Isola, Venire..., p. 427.

23 L. Isola, Venire..., p. 428-429.
} 
its assessment used to protect such a value. In this context, the Austrian author underlines favour for freedom (favor libertatis). ${ }^{24}$ Should they strictly follow the structure of Azo's Brocardia, the contemporary reader can easily notice elements of systemic thinking about the application of the maxim in the medieval handbook of legal reasoning, thanks to the work of Lisa Isola. There are a few levels of differentiation in the closing fragment of the Brocardia ${ }^{25}$ - which I would call Azo's matrix. Behaviour contrary to the maxim the way of thinking about the role of the venire contra factum proprium maxim in the legal reasoning of the late Middle Ages. Lisa Isola can be given credit for explaining this important part of legal history to the contemporary reader. The conclusions of ancient jurists, presented thoroughly by the Austrian author, definitely included inspirations for a kind of method of using the discussed maxim which has been crystallising since the late Middle Ages. However, in my opinion, we can go further in our reflections about elements

\section{The contemporary reader can easily notice elements of systemic thinking about the application of the maxim in the medieval handbook of legal reasoning.}

was generally excluded when it violated a previous lawful act (factum legitimum). However, exceptions to such a connection with the maxim - resulting from Roman texts - were allowed. ${ }^{26}$ The acts not included in facta legitima were divided into two groups. The first was constituted by acts made against a legal prohibition (factum lege prohibente). It was possible not to observe them in later behaviour. The second group was constituted by acts which are unclear for the contemporary lawyer, in the case of which "the law was non-present" (factum lege non asistente). They had to be observed. The cases of acts which did not meet the form required by law $^{27}$ were dominant among Roman examples justifying the distinction of the last of the indicated groups. On the occasion of the presentation of the principles formulated by Azo, the Austrian authoress indicated another classification of the application's fields of the maxim. This other classification was presented by Baldus in his commentary on the Justinian code. This brief mention tells us that the so-called Azo's matrix constituted only a part of

\footnotetext{
24 L. Isola, Venire..., p. 384 i 431.

25 Brocardia..., p. 123.

26 See C. 7,16,1 (favor liberorum); C. 8,44,25 (favor libertatis).

27 D.1,7,25pr.; D.8,3,11; I,2,23,12.
}

of the systemic thinking about the maxim by lawyers ius commune than Lisa Isola did when formulating two accurate, yet general, findings. Firstly, she stated that it was of key importance for the authors of the maxim to set the limits of being bound by a performed act, not to protect another person's trust. ${ }^{28}$ Secondly, she confirmed that the discussed maxim - just like many other maxims formulated in the Middle Ages - renders it easier to go through Corpus Iuris Civilis in the first place. ${ }^{29}$

I believe that further searching for answers to the above questions asked by me needs a change of approach to the sources. Lisa Isola placed the ancient texts included in Azo's Brocardia at the heart of her explanations of the venire contra factum proprium maxim. In my opinion, such an approach is worth being replaced by focusing on sources which explain the history of the maxim from the late Middle Ages to civil codifications. In such case, sources selected pars pro toto from an extensive, dispersed and largely unexplored mass of ius commune sources can constitute the basis for consideration. We will see if going this way can mitigate the embarrassment of the contem-

\footnotetext{
28 L. Isola, Venire..., p. 387-388.

29 L. Isola, Venire..., p. 425.
} 
porary lawyer towards the sense of the venire contra factum proprium maxim, which has been repeated for centuries.

\section{The oldest traces of the maxim}

\subsection{The origins of the maxim in light}

of the Digestum vetus manuscript kept in the Kórnik Library

The reading of a text from the Opinions of Ulpian, a jurist of the $2^{\text {nd }}$ and $3^{\text {rd }}$ centuries, kept through the Justinian Digests, allows one to come to the conclusion that the language of the discussed maxim was anciently inspired. The Roman jurist was considering the problem of whether a father could question the effectiveness of his daughter's testament if her testamentary capac- no quem non posse venire adversus factum suum. ${ }^{33} \mathrm{~A}$ further part of the explanation includes a distinction between cases when an act was made against the law (faciat quod est prohibitum a lege) and when it was not prohibited by the law non est prohibitum). The Roman conclusion acknowledging the fact that the father was bound by the executed emancipation was classified by medieval jurists as an act belonging to the second group. They stated that the father did not violate the law but omitted the requirements of formality (omissa illa solemnitatem). This very part of the manuscript shows that the Roman explanation ratio decidendi triggered the formulation of the maxim, with which the question of its binding power has been connected since its beginning - probably and finally in the $12^{\text {th }}$ century. The consistency of the content core between

\section{The maxim has never been treated either in a simplified or an absolute way.}

ity was based on emancipation (emancipatio) which the father had executed without observing formal requirements. The jurist excluded the possibility of claiming that the emancipation was not made legally by justifying this concisely in that the father could not proceed against his own act (adversus factum suum.. prohibetur). ${ }^{30}$ The manuscript of the first part of the Justinian Digests - dated at the turn of the $12^{\text {th }}$ and $13^{\text {th }}$ centuries and kept in the Kórnik Library ${ }^{31}$ - shows that in the discussed Ulpian's text, the word factum drew the attention of glossators. The explanation thereof added probably as part of updating the manuscript in the $13^{\text {th }}$ century ${ }^{32}$ - begins with a paraphrasing of the words of the Roman jurist with the following:

30 D. $1,7,25$ pr.

31 See J. Frońska, The Memory of Roman Law in an Illuminated Manuscript of Justinian's Digest (in:) E. Brenner, M. Cohen, M. Franklin-Brown (eds.) Memory and Commemoration in Medieval Culture, Farnham 2013, p. 164.

32 Zob.: J. Frońska, The Memory..., p. $164 \mathrm{ff}$. the wording of the gloss in the manuscript and in its more extended printed version ${ }^{34}$ renders it possible to conclude that the maxim has never been treated either in a simplified or an absolute way.

\subsection{Including the maxim in Azo's Brocardia}

The Brocardia, ${ }^{35}$ a collection of legal maxims compiled and most probably supplemented by Azo, is a legal text which is useful when solving legal problems. One of its rubricas (sections) is dedicated to the unambiguity of acts (De aequalitate factorum). ${ }^{36}$ Judging by the wording of thirty-five maxims collected therein, the aim of this rubrica was to render it easier to assess when and which legal consequences can be connected with a specific act. All the max-

\footnotetext{
33 BK 824, p. 21.

34 See Corpus Iuris Civilis. Digestum vetus, vol. 1, Lugduni 1627, p. 68.

35 See H. Lange, Azón (+ ca. 1220) (in:) R. Domingo (ed.) Juristos universales, vol. 1, Madrid 2004, p. 383.

36 Brocardia..., p. 103-130.
} 
ims were linked to respected texts, mainly stemming from Roman law. This rubrica includes unambiguous guidelines such as the following: an action or omission shows the intention (ex facto vel non facto animus est eventus) ${ }^{37}$ a later delict or action does not harm what was correctly done (quod recte factum est, superveniente delicto vel facto non vitiatur), ${ }^{38}$ and the statement that if a person does not do what they should, it is assumed that they do what they should not (qui non facit quod facere debet, intellegitur facere quod non debet). ${ }^{39}$ There are also mutually exclusive maxims ${ }^{40}$ or questionable ones, which were expressed by the fact that the quoted legal sources include texts which both confirm the maxim and which are contrary to it (contra) ${ }^{41}$ The venire contra proprium factum nulli conceditur maxim, which is included in the ending part of the rubrica, belongs to the last of the mentioned groups. ${ }^{42}$ Considering the purpose and content of Brocardia's rubrica in which it was added, we can conclude that it was not of an especially argumentative or normative status. In the Brocardia, it was one of many elements used to subordinate the assessment of acts (facta), with which legal consequences are connected. It specified the richness of such situations. Explanations regarding the scope of application of the maxim in the Brocardia directed rather than decided on a legal assessment. They reminded one about the necessity of assessments valuing inconsistent behaviour. We can assume that creating the venire contra factum proprium prohibition in the Brocardia by Azo, a jurist who was significantly distinguished by his authority and influence among lawyers contemporary to him, ${ }^{43}$ contributed to drawing more attention to problems connected with the maxim. For instance, a collection of legal principles of renowned jurists of

37 Brocardia..., p. 103.

38 Brocardia..., p. 113.

39 Brocardia..., p. 124.

40 Brocardia..., p. 119: quod fieri debet, non nocet omissum esse and quod fieri debet, nocet omissum esse.

41 E.g. Brocardia..., p. 109-111: quod non est, videtur esse, quia potest esse.

42 Brocardia, p. 121-123.

43 H. Lange, Römisches Recht..., p. 260; Azo and Accursius were the only glossators to have a significant impact in the following centuries. the late Middle Ages which was published at the end of the $16^{\text {th }}$ century included in comments regarding acts (factum) a range of maxims coming from the rubrica (section) entitled De aequalitate factorum in Azo's Brocardia. ${ }^{44}$ In particular, explanations concerning the venire contra proprium factum maxim ${ }^{45}$ were repeated in full therein. The question of how to reconcile its flexibility with some subordination of legal thinking, which was clear thanks to Azo's Brocardia, was taken by following generations of jurists of the late Middle Ages.

\section{Late medieval schemes specifying the application of the venire contra proprium factum maxim}

Petrus de Bellapertica (1250-1308), a professor of law in New Orleans and Toulouse, was one of the forerunners in legal method. It consisted of assigning a key role - as in philosophy ${ }^{46}$ - to special distinctions (distinctiones) and striving at the precision of argumentation systematised this way. ${ }^{47}$ Such a methodological approach also brought a slightly richer explanation regarding the scope of application of the discussed maxim. Bellapertica's disquisition started with stating that the maxim did not apply to revocable acts (factum de sua natura est revocabile). ${ }^{48}$ With regard to acts which are irrevocable by their nature (de sui natura non est revocabile), the French jurist gave special importance to the connection between the validity of the maxim and the foulness (turpitudo) of the person performing the acts. He thought that a person acting justly is not bound by an act which they performed against the law (contra legem). Whereas with regard to lawful acts (secundum legem), he declared that there can be deviations from being bound by the maxim for certain reasons. He found that they occur in the case

44 I. Baptista Nicolaus, Regularum iuris civils quam pontificii ex celeberrimis et excelentissimis doctoribus, vol. 2, Francofurti ad Moenum 1586, p. 444-450.

45 I. Baptista Nicolaus, Regularum..., p. 449-450.

46 G. Guyon, Pierre de Belleperche (1250-1308) (in:) R. Domingo (ed.), Juristos universales, vol. 1, Madrid 2004, p. 480.

47 H. Lange, M. Kriechbaum, Römisches Recht im Mittelalter, vol. 2, Kommentatoren, München 2007, p. 556.

48 P. de Bellapertica, Quaestiones et decisiones aureae, Basileae 1607, p. 162. 
of unfairness of the other party of a given act who committed fraud or duress. ${ }^{49}$ The flexibility of the maxim's application, noted from the beginning, was here clearly linked with the protection of the effects of the act which a person acting in a lawful and just way can expect. by the legally invalid emancipation as an example of the validity of the maxim in relation to acts made outside of the law (praeter legem). However, he drew attention to heterogeneity of using the maxim in cases specified this way. ${ }^{54}$ As to acts made against the law (contra legem), Bartolus specified explanations of the

\section{The aspiration of medieval jurists to specify exceptions from the venire contra factum} proprium maxim found its theoretical crowning in the commentary of Baldus de Ubaldis.

The commentary of Bartolus de Saxoferrato (1313-1357) on a part of the Justinian Digests which inspired the maxim ${ }^{50}$ shows that this grand-disciple $^{51}$ of Petrus Bellapertica, who was one of the most influential European lawyers until the $16^{\text {th }}$ century, chose the path of a creative synthesis of understanding the maxim. Similar to Bellapertica, he took the division into revocable and irrevocable acts as the starting point. He clearly confirmed the non-application of the maxim in the case of the first group, illustrating it with an example of a will and a death-bed gift (donatio mortis causa). ${ }^{52}$ With regard to acts which are irrevocable by their nature, Bartolus clearly followed the scheme of the trifurcation of the gloss. However, he modified it towards Azo's Brocardia. Bartolus distinguished three intensity levels of deviation from the maxim. In the case of a lawful act (secundum legem), he allowed for deviations exceptionally in specific cases. ${ }^{53}$ The jurist specified the mentioned text with regard to the fact of it being bound

49 P. de Bellapertica, Quaestiones..., p. 162.

50 D.1,7,25pr

51 G. Guyon, Pierre..., p. 482.

52 Bartollus de Saxoferrato, Commenmtaria, vol. 1, Digstum vetus, Venetis 1516 (repreint Roma 1998), col. 31.

53 His comment reffering to the glossa ordinaria and opinions of doctores is consistent with the Brocardia of Azo. gloss in such a way that he linked the lack of being bound by the maxim with acting in the public interest or in the interest of a party affected by such an act. ${ }^{55}$

The aspiration of medieval jurists to specify exceptions from the venire contra factum proprium maxim found its theoretical crowning in the commentary of Baldus de Ubaldis (1327-1400), a disciple of Bartolus who gained similar authority in the European legal science of the $15^{\text {th }}$ and $16^{\text {th }}$ century. ${ }^{56}$ He focused on a systematic presentation of differences in the field of deviations from the venire contra factum proprium prohibition. ${ }^{57}$ Baldus divided them into four groups. He excluded the application of the maxim in a situation when an act was not supposed to lead to the creation of a legal duty. ${ }^{58}$ The jurist also explained that if a given act did not cause an intended legal effect (actus non valuit), the principle is basically not binding. However, it is sometimes possible to follow it and, in such situations, he illustrated it with the fact of it being bound

54 E.g. C.11,48,7 cited as an example of a praeter legem act.

55 Bartollus de Saxoferrato, Commenmtaria..., col. 31: ...aut per favorem publicum aut favore volentis contravenire...

56 See H. Lange, M. Kierchbaum, Römisches Recht..., p. $751 \mathrm{ff}$.

57 Baldus' comment referred to the withdrawal from the sale of a seller's child (C. 7,16,1).

58 Baldus de Ubaldis, Super VII, VIII et IX Codicis commentaria, Lugduni 1539, p. 11: ...faciendo de facto non de iure. 
with the formally incorrect emancipation. Previously, this case had been classified in a less clear way as an act made when "the law was absent" (factum lege non asistente) ${ }^{59}$ or as an act made outside of the law (praeter legem).${ }^{60}$ Whereas in a situation when a given act caused intended legal effects (actus est ad solutionem), Baldus - inspired by Roman texts - allowed for two groups of exceptions to being bound by the maxim: acting on someone else's behalf ${ }^{61}$ and behaviour based on favour for freedom. ${ }^{62}$

The outlined output of late medieval legal science shows that the flexibility of the application of the venire contra factum proprium prohibition, noted from the very beginning, triggered a search for a scheme which renders it easier to use the maxim in legal reasoning. With the aim of offering a more a dogmatic assessment - inspired largely by Roman texts - with an order to consider the foulness of the person performing a given act or the protection of certain values or interests. Such an approach to the maxim became a point of reference to it in the $16^{\text {th }}$ and $17^{\text {th }}$ century. This was the time when practice willingly followed schemes which were organising legal reasoning and a new systematic law order began to be sought in jurists' debate.

\section{The presence of the venire contra factum} proprium nemini licet maxim in jurists' debate from the $15^{\text {th }}$ until the $17^{\text {th }}$ century

It is significant that the manual of legal argumentation by Nicolaus Everard, Topicorum seu de loci legalis, ${ }^{63}$ published for the first time in 1516 - consid-

\section{Papers connected with legal practice constitute a field of ius commune which ensured the duration of the discussed maxim.}

precise meaning of such a scheme, the field of the application of the maxim has been clearly restricted to acts (facta) which were supposed to lead to the creation of a legal duty. We can also notice a striving for the certainty of dogmatic assessment criterion of the validity acts (a clear antinomy of contra and secundum legem or actus non valet and actus ad solutionem). This was accompanied by underlining the flexibility of the consequences of such an assessment, which was made in several ways; firstly, by making reference to respected Roman sources which include solutions breaking the venire contra factum proprium prohibition. Secondly, by linking the consequences of

59 Brocardia..., p. 123.

60 Bartollus de Saxoferrato, Commentaria..., col. 31.

61 Baldus de Ubaldis, Super VII, VIII et IX Codicis..., p. 11: ... Ipso iure non tenet agit volle alieno.

62 Baldus de Ubaldis, Super VII, VIII et IX Codicis ..., p. 11: ... libertatis favorem. ered nowadays as one of the most important books in European legal culture ${ }^{64}$ - does not include the maxim forbidding venire contra factum proprium. Nor was it included in an extended version of this work. ${ }^{65}$ Papers connected with legal practice constitute a field of $i u s$ commune which ensured the duration of the discussed maxim. Even a very limited reading of these kinds of papers makes it possible to believe that early modern jurists were following trends in setting the limits of being bound by the venire contra factum prorpium prohibition, which were visible in the late Middle Ages.

63 N. Everardus, Topicorum seu de locis legalibus, Lovanium, 1516.

64 See A. Wijffels, Everardus. A Book on Topics (in:) S. Dauchy, G. Martyn, A. Musson, H. Pihlajmäki, A. Wijffels (eds.) The Formation and Transmission of Western Legal Culture. 150 Books that Made the Law in the Age of Printing, 2016, p. 65-67. 65 See N. Everardus, Argumentorum legales, Lugduni 1568. 
5.1. Application of the venire contra factum proprium prohibition and the purely dogmatic approach to legal transactions effects

A dogmatically clear connection between being bound by one's own act and its legal validity which was made by Baldus (actus ad solutionem) was incor- criterion which links the assessment of being bound by an act (factum) with its legal effectiveness. He stated that a person can act against their own act which is not enforced by law (iure improbatum). ${ }^{70}$ An opinion of Ioannes Surdus, ${ }^{71}$ a jurist who lived in the second half of the $16^{\text {th }}$ century, confirms the proliferation of the

\section{Cases regarding the fact of being bound} by the consequences of an invalid act became a focus point in reflections about the boundaries of the application of the maxim.

porated by him - as a principle - into practice which consisted in providing legal opinions. ${ }^{66}$ Such a determination of one of the limits of the venire contra factum proprium prohibition was maintained by Alexander Tartagus (1423/24-1477), a disciple of Baldus, whose opinions were highly respected. ${ }^{67}$ In one of his opinions, he assessed a dispute whose starting point was an agreement on the disposal of real property concluded without formalities for transferring the property of land. He explained that despite the consenting to and transfer of the real property, no effective transaction took place ${ }^{68}$ and therefore, the venire contra factum proprium prohibition was not applicable. ${ }^{69}$ An explanation accompanying the assessment of an invalid lease contract, included in the opinion of Roberto Marante (1490-1539), an Italian jurist of the $16^{\text {th }}$ century - indicates the consolidation of the

66 See Baldus de Ubaldis, Repertorium in omnia consiliorum, Venetiis 1580, p. 104: ...quis potest venire contra factum suum, quando est ipso iure nullum.

67 See F. Cuena, Alejandro Tartaña (1423/1424-1477) (in:) R. Domingo (ed.) Juristos universales, vol. 1, Madrid 2004, p. 556-557.

68 A. Tartagnus, Consiliorum seu responsorum, $2^{\text {nd }}$ book, Venetiis 1610, Cons. XCIII, p. 81: Consensus simplex non confert titulum.

69 A. Tartagnus, Consiliorum..., p. 81: Venire quis potest contra factum suum nullum. dogmatically clear limit of the discussed prohibition. A dispute about a testator's donation constituted an occasion for jurists to make comprehensive considerations $^{72}$ about the validity of the maxim prohibiting venire contra factum proprium, which has many references to legal literature. Also in this case, at the beginning of argumentation was the statement that anyone can act against a performed action if the act is invalid (nullum). ${ }^{73}$ However, striving for clarity in legal reasoning did not undermine the flexibility of the venire contra factum proprium prohibition. The bases for challenging an act made as a result of fraud or duress, ${ }^{74}$ inspired by Roman law, were indicated as an exception to this prohibition, justified by equity (ex summa aequitate). However, cases regarding the fact

70 R. Maranta, Conislia sive responsa, Coloniae Agrippinae 1599, Cons. XXIX, p. 148: ...potest quis venire contra factum proprium, quando fuit illicitum vel invalidum, et iure improbatum...

71 See Chr. v. Bar, P. Dopffel (eds.), Deutsches Internationales Privatrecht im 16. und 17. Jahrhundert, vol. 1, Tübingen 1995, p. 643

72 See E. Riezler, Venire..., p. 45.

73 I. P. Surdus, Consiliorum sive rsponsorum, $2^{\text {nd }}$ book, Francofurti ad Moenum 1630, Cons. CCLXXXIV, p. 934-936: Factum proprium impugnare potest quilibet, si est nullum..

74 A. Faber, Codex Fabrianus definitionum forensium et rerum in sacro Sabaudiae Senatu, Lugduni 1610, p. 129; N. Acosta, Tractatus de privilegiis credito, 1645, p. 99. 
of being bound by the consequences of an invalid act became a focus point in reflections about the boundaries of the application of the maxim.

\subsection{Criterion of the interest or justice of behaviour} and the application of the maxim in the case of the invalidity of an act

Connecting the venire contra factum proprium prohibition with the result of a dogmatic assessment as well as with the result of based on the values evaluation of an act, which was visible in the case of late-medieval lawyers, found its creative continuation. We can find functionally consistent opinions in the legal literature of the $15^{\text {th }}$ and $16^{\text {th }}$ centuries which show how a dogmatic assessment of being bound by an act (factum) was supplemented by a reference to the honesty of a tion provided by Antoine Favre (1557-1624) can be perceived as an example of extension in the direction of strengthening the venire contra factum proprium prohibition. This influential representative of French legal humanism assumed the discussed maxim as an argument confirming the fact of being bound by an act when the act consisted in the intentional approval of improper behaviour. ${ }^{77}$

The flexibility of the venire contra factum proprium prohibition, noticed from the very beginning, was visibly based on Roman sources in the late Middle Ages. The output of ius commune allowed Ioannes Surdus to make the synthetic statement that deviations from the principle of binding of the party by his/her legally valid action are possible in the public interest $^{78}$ or in the interest of an entity which was

\section{Linking the maxim with a practical}

\section{description of applied Roman law closed the possibility for innovation.}

person performing the act and taking into consideration interests which are worth protecting. As a matter of fact, such considerations came down to searching for an answer to the question whether and to what extent a person who performed an invalid act can act against it.

A reading of the mentioned opinion of Ioannes Surdus renders it possible to acknowledge that in legal discussions of the $16^{\text {th }}$ century, an opinion was formed according to which the invalidity of an act could not be invoked by a person who, by acting in an unjust way, caused the invalidity of the act and wanted to use that in their own interest ${ }^{75}$ or in the interest of a person for whom the invalidity was caused. ${ }^{76}$ The explana-

75 I. P. Surdus, Consiliorum..., p. 935: ... quod faciens pactum prohibitum favore tertii contravenire non possit, (...) quod contractus est nullus, quoad alios non ad facientis commodum.

76 I. P. Surdus, Consiliorum..., p. 935. ...non placet, quia ubi actus annullatur favore alterius, si solus allegat nullitatem, in cuius favorem fuit inducta... represented by the person performing a given act ${ }^{79}$ or in the case of faultless violation of the formalities of an act required by law. ${ }^{80}$

The presented outline of references to the venire contra factum proprium prohibition in the opinions of jurists of the $15^{\text {th }}$ and $16^{\text {th }}$ centuries enables one

77 A. Faber, Codex Fabrianus..., p. 129: ... restitui non potest ad improbandum factum procuratoris quod ipse semel approbaverit - nemo enim factum proprium impugnare potest...

78 I. P. Surdus, Consiliorum..., p. 934-935: Factum proprium impugnare quis potest, quando anullatur favore publico (...) Resopndeo etiam contrarium procedere, quando actus anullatur favore publico.

79 E.g. I. P. Surdus, Consiliorum..., p. 934-935:Praelatus potest nomine ecclesiae impugnare alienationem, quam nullam fecit: ...venire potest contra proprium contractum, ex quo gerit duplicem personam, et impugnat alieno nomine...

80 I. P. Surdus, Consiliorum.... p. 935:... potest impugnare factum proprium nullum, quando actus simpliciter non prohibetur, sed datur certa forma servanda, qua non servata annullatur.. 
to notice that subsequent trends from the late Middle Ages came with modifications. Their essence lay in clearly focussing on the fact of being bound by an invalid act by the person who performed that act. In that area, distinctions in terms of assessment regarding the fairness of the behaviour of the person performing a given act and justified interests of other entities were proliferated. Examples of references to the venire contra factum proprium maxim consistent with those defence was chaired by Samuel Stryk, namely the person who was setting directions for legal practice usus modernus at the beginning of the $18^{\text {th }}$ century. ${ }^{82}$ At the beginning of his dissertation Johann Schacher stressed that stability and loyalty bring glory to people, however, the law sometimes allows deviations from the principle ordering such behaviour. The work focuses on an extensive presentation of manifestations of the principle and exceptions thereof. ${ }^{83}$ Explanations of the nature of the

\section{The maxim had equally marginal} importance in German pandectisim.

regularities can be found also in legal reasoning in the $17^{\text {th }}$ century. ${ }^{81}$ However starting from that century, such usage of the maxim has been accompanied by searches for new legal methods. In the German states, the focus was placed on striving to help practitioners to "go through the obscurities" of applied Roman law. Searches for a new systemic order of the law brought about more significant changes. They constituted the foundations for the theories underlying civil codifications of the $19^{\text {th }}$ century. Different purposes of developed legal methods resulted in a different approach to the maxim prohibiting venire contra factum proprium.

\section{Significant differences of importance assigned to the maxim in the systemic approach to the law from the $17^{\text {th }}$ century until the $19^{\text {th }}$ century}

\subsection{The venire contra factum proprium maxim as an axis of a description of applied Roman law}

On $11^{\text {th }}$ April 1688 the Council of the Law Faculty of the Viadrina University in Frankfurt (Oder) approved a dissertation by Johann Schacher regarding the legal possibility of behaviour contrary to an act performed before (De impugnatione factii proprii). The dissertation

81 E.g. I. Brunnemann, Commentarius in Codicem Iustinianeum, Lispae 1708, p. 1279. principle show that it was linked with the ultimacy of the legal consequences of valid acts ${ }^{84}$ and the impossibility of invoking unjust behaviour by a person who led to the invalidity of acts. ${ }^{85}$ A bigger part of the text - organised in five chapters - was constituted by a description of legal rules specifying the principle and allowing for revoking the consequences of a legal act. Schacher's reasoning was based on Roman law used in the religious and political context of absolutist monarchies. The spirit of his considerations may be illustrated by examples of exceptions from the principle, such as: the dissolution of marriage due to a violation of marital fidelity, ${ }^{86}$ the withdrawal from a sales agreement due to the defects of a thing, ${ }^{87}$

82 Cf. F. Wieacker, Privatrechtsgeschichte der Neuzeit, Göttingen 1967, p. 220.

83 J. Ch. Schacher, Disputatio iuridica. De impugnatione facti proprii, 1688, p. 3-4.

84 J. Ch. Schacher, Disputatio..., s. 9: ...Pacta itaque dum servanda diximus, (...) Sicuti enim quis venire non potest contra $i d$, quod voce propria fuit attestatus...

85 J. Ch. Schacher, Disputatio..., p. 12: ...Senatus contractum non potest impugnare, forte ex eo capite, quod sine consensu civum fuerit initus (...) Turpitudunem vereo propriam regulariter nemo allegare potest.

86 J. Ch. Schacher, Disputatio..., s. 26 (the chapter on the law of persons).

87 J. Ch. Schacher, Disputatio..., s. 50 (the chapter on legal transactions inter vivos). 
the revocation of a will, ${ }^{88}$ the change of position in an appeal procedure, ${ }^{89}$ a withdrawal from the disposing of church real estate made without legitimate cause ${ }^{90}$ or the breaking of an agreement by a sovereign if he has a good reason for doing so. ${ }^{91}$ Such use of the principle meant a significant change in the approach to explaining its flexibility. On one hand, it put the argumentative value of the venire contra factum proprium nemini licet maxim on an equal footing with the maxim excluding the possibility of invoking own foulness (turpitudinem suam that the maxim was present in the argumentation of practitioners $^{92}$ and in collections of legal maxims ${ }^{93}$ also in the times of the codifications of the $19^{\text {th }}$ century. However, it was not included in explanations about the bases and scope of the reliance in the fundamental works of the rational school of the law of nature. ${ }^{94}$ Consequently, the maxim did not become a visible element of discussions from which the first modern civil codes originated, such as, in French Code Civil ${ }^{95}$ in particular. The maxim had equally

\section{Focus on the discussed maxim by Erwin} Riezler in the first years of codified private law in Germany was linked with a thesis on limitations resulting from codification.

allegans nemo audiatur), which is also well-established in practice. On the other hand, it made the maxim become only a guideline, helping to present the extensiveness and diversity of dogmatic considerations which focused on the possibilities of acting against a performed legal or procedural act. Such an approach could have consolidated the maxim's presence in legal argumentation. However, linking the maxim with a practical description of applied Roman law closed the possibility for innovation.

\subsection{The marginalization of the maxim in dogmatic reflections of theories from which contemporary civil codes originated}

Permanent inclusion of the maxim in European legal science based on Roman texts resulted in the fact

88 J. Ch. Schacher, Disputatio..., s. 59 (the chapter on mortis causa acts).

89 J. Ch. Schacher, Disputatio..., s. 83 (the chapter on proceedings in law).

90 J. Ch. Schacher, Disputatio..., s. 85 (the chapter on acts in ecclesiastical matters).

91 J. Ch. Schacher, Disputatio..., s. 105 (the chapter on the binding of a sovereign by his acts) marginal importance in German pandectisim, which created an original theory of legal transactions. An exception in that German legal discussion of the $19^{\text {th }}$ century was constituted by the use of the maxim as an argument for combating the dishonesty (exceptio doli generalis) of a husband who was demanding the return of dotal land sold by him contrary to the law. ${ }^{96}$ According to such a way of thinking, remembering about the maxim in legal discussions resulted in the paper of Ernest Riezler, which I have already mentioned. ${ }^{97}$ It was published twelve years after the

92 E. Rezler, Venire..., p. 54.

93 E.g. F. Vaccaro, Juris aphorismi ordine alphabetico digesti, Napoli 1842, p. 45.

94 Cf. H. Grotius, De jure belli ac pacis, Amstelaedeami 1720, p. 436 (Lib. II, cap. XV, XIV-XV); S. Puffendorf, De jure naturae et gentium, Francofurti ad Moenum 1684, p. 386-388

(Lib. III, cap. 4, \$1-2);

95 The drafters of Code civil have not adopted the binding effect of an offer.

96 A. Brinz, Lehrbuch der Pandekten, $2^{\text {nd }}$ edition, vol. 3, Erlangen 1888, p. 697, fn. 32.

97 See above: $p$. 
introduction of the German Civil Code, which was based on the pandectist theory of private law.

\section{Conclusions}

Since the moment of the creation of the venire contra factum proprium nemini licet maxim in the late Middle Ages, lawyers have been noticing the flexibility of its application. Its history in the theory and practice of the pre-codification period can be determined synthetically as specifying the consequences of that in the case of a faultless violation of the formalities of an act required by law. The culmination of such a way of thinking about the venire contra factum proprium prohibition can be noticed in the seventeenth-century science of then-applied Roman law (usus modernus). It consisted in the fact that being bound by an act by a person who wrongly caused its invalidity was linked with the maxim excluding the possibility of invoking the consequences of one's unjust behaviour in one's own interest (turpitudinem suam allegans nemo audia-

\section{The immanent flexibility of the maxim should} inspire moderation in declaring the venire contra factum proprium prohibition as one of the basic principles of private law.

flexibility for legal reasoning. We can see elements of a systemic approach in this type of attempt. A discussion on this was opened by Azo's Brocardia dated at the end of the $12^{\text {th }}$ century. His work shows that at the beginning of the setting of different intensity areas of being bound by the maxim, the most difficult thing was to generalise the differences of being bound by acts which did not comply with the required formalities of a transaction. In the course of discussions of jurists of the $13^{\text {th }}$ and $14^{\text {th }}$ centuries, this was developed within the connection of the application of the maxim with the assessment of act validity. Consequences of such an assessment were corrected using criteria referring to the fairness of the behaviour of a party which caused the invalidity of a given act as well as values or interests inspired by Roman legal texts. According to the sources, we can assume that inspirations stemming from such an approach led, in the $15^{\text {th }}$ and $16^{\text {th }}$ century, to focussing on the question about being bound by the maxim by a person who performed an invalid act. Permitted cases of acting against such an act by the person who performed it included acting in the public interest or in the interest of a party which was represented by the person performing a given act and tur). However, the presence of the maxim prohibiting venire contra factum proprium did not result in including it in legal discussions from which private law theories constituting foundations for codification originated, in particular, the pandectist theory of legal transactions. Even so, we can indicate a range of codification provisions which can be linked with the maxim; ${ }^{98}$ the experience behind it was not used when developing provisions coming from theoretical considerations about legally relevant behaviours.

Focus on the discussed maxim by Erwin Riezler in the first years of codified private law in Germany was linked with a thesis on limitations resulting from codification. He drew attention to the fact that it limits

98 For German Civil Code: E. Riezler, Venire..., p. 110-123, e.g.: Sec. 116 (mental reservation); Sec. 145 (binding effect of an offer); Sec. 151 (acceptance without declaration to the offeror); Sec. 164 p. 3 (effect of a declaration made by the agent); Sec. 226 (prohibition of chicanery). For Italian Civil Code: F. Festi, Il divieto..., p. 2-5: e.g.: Sec. 367 (statement about the guardian's debts and claims towards the minor), Sec. 590 (confirmation or voluntary fulfilment of the wills disposition); Sec. 1059 (easement created by a co-owner); Sec. 1372 (principle - agreements must be kept); 
access to legal past. Riezling found that such access can help in finding praeter legem solutions, which will be used where "the statutory regulations do not provide satisfactory protection of interests" (der Gesetzeswortlaut den Bedürfnissen nach Interessenschutz nicht Genüge tut). ${ }^{99}$ In this context, he presented the venire contra factum proprium prohibition as a legal idea which can support the achievement of such results. ${ }^{100}$ Postulating references to the maxim in order to combat benefiting from dishonesty (exceptio doli generalis), he drew attention to potential possibilities rooted in declaring the venire contra factum proprium prohibition as one of the basic principles of private law. This moderation strengthens the absence of the maxim in legal topics collection by Nicolaus Everard, which is significant for legal argumentation in the pre-codification period, and in the works which are fundamental for modern civil codifications. Secondly, the connection of the discussed maxim with the objection against benefiting from unfair behaviour, which stands out in historical experience, should inspire the possibly of a wide usage of the maxim in such a way. ${ }^{102}$

\section{Legal experience inspires the consideration of the adoption of a new statuatory rule referring to the legal effects of a legal transaction.}

general clauses. Legal science and practice showed that such an idea found its substantiation in an interpretation of the good faith clause based on the doctrine of abuse of law or protection of reliance. ${ }^{101}$ In such argumentative practice - which, however, raises doubts as to the usefulness of the maxim - we can notice functional similarities between the practice of pre-codification times and using modern theories ad casum. However, I think that the limitations in access to legal experience, which were signalled by Riezler more than a hundred years ago, are still valid in modern debate about the maxim venire contra factum proprium nemini licet.

The presented outline of those experiences constitutes the basis to put a few remarks under the consideration of a contemporary lawyer. Firstly, the immanent flexibility of the maxim should inspire moderation in

99 E. Riezler, Venire..., p. 126.

100 E. Riezler, Venire..., p. 128.

101 E.g.: Sec. 242 German Civil Code; Sec. 5 Polish Civil Code. This trend in legal dogmatic is consictent with intuitions of ancient jurists, cf. F. Longchamps de Bérier, L'abuso del diritto nell'esperienza del diritto privato romano, Torino 2013, p. 211; W. Dajczak, The Nature of the Contract in Reasoning of Civilian Jurists, Poznań 2012, p. 29, fn. 80.
And finally, the effect of being bound by an act by a person who wrongly caused its invalidity, which has been based on the maxim in pre-codification legal practice, is worth thinking through in the world of developed theories of legal transactions. Legal experience inspires the consideration of the adoption of a new statuatory rule referring to the legal effects of a legal transaction. In specific cases, the new rule would force one to treat an invalid legal transaction as valid. The factors connected to the adoption of this hypothetical rule would be two-fold; firstly, the invalidity of a legal transaction would have to be the result of the unfair behaviour of a person who would benefit from its invalidity. Secondly, treating the legal transaction as valid would have to not violate public interest or the legitimate interest of others.

\section{Bibliography \\ Acosta N., Tractatus de privilegiis credito, 1645. \\ Astone F., Venire contra factum proprium, Napoli 2006. \\ Baldus de Ubaldis, Super VII, VIII et IX Codicis commentaria, Lugduni 1539.}

102 Cf. A. Stelmachowski, Zarys teorii prawa cywilnego, Warszawa 1998, p. 128. 
Baldus de Ubaldis, Repertorium in omnia consiliorum, Venetiis 1580 .

Baptista Nicolaus I., Regularum iuris civils quam pontificii ex celeberrimis et excelentissimis doctoribus, vol. 2, Francofurti ad Moenum 1586.

Bar v. Chr, Dopffel P. (eds.), Deutsches Internationales Privatrecht im 16. und 17. Jahrhundert, Tübingen 1995, vol. 1.

Bartollus de Saxoferrato, Commenmtaria, vol. 1, Digstum vetus, Venetis 1516 (reprint Roma 1998)

Bellapertica P., Quaestiones et decisiones aureae, Basileae 1607.

Brinz A., Lehrbuch der Pandekten, $2^{\text {nd }}$ edition, Erlangen 1888 , vol. 3.

Brocardica Azoni sive generalia iuris Azonis Bononiensis, Basileae 1567.

Brunnemann I., Commentarius in Codicem Iustinianeum, Lispae 1708.

Corpus Iuris Civilis. Digestum vetus, Lugduni 1627, vol. 1.

Cuena F., Alejandro Tartaña (1423/1424-1477) (in:) R. Domingo (ed.) Juristos universales, Madrid 2004, vol. 1, pp. 556-557.

Dajczak W., The Nature of the Contract in Reasoning of Civilian Jurists, Poznań 2012.

Dette H. W., Venire contra factu proprium nulli conceditur. Zur Konkretisierung eines Rechtssprichtwortes, Berlin 1985.

Everardus N., Topicorum seu de locis legalibus, Lovanium, 1516. Everardus N., Argumentorum legales, Lugduni 1568.

Faber A., Codex Fabrianus definitionum forensium et rerum in sacro Sabaudiae Senatu, Lugduni 1610.

Festi F., Il divieto di "venire contro il fatto proprio", Milano 2007.

Frońska J., The Memory of Roman Law in an Illuminated Manuscript of Justinian's Digest (in:) E. Brenner, M. Cohen, M. Franklin-Brown (eds.) Memory and Commmoration in Medieval Culture, Farnham 2013.

Grotius H., De jure belli ac pacis, Amstelaedeami 1720.

Guyon G., Pierre de Belleperche (1250-1308) (in:) R. Domingo (ed.), Juristos universales, Madrid 2004, vol. 1, pp. 480-483.
Isola L., Venire contra factum proprium. Herkunft und Grundlagen eines sprichwörtlichen Rechtsprinzips, Frankfurt am Main 2017.

Jansen N, Zimmermann R. (eds.), Commentaries on European Contract Law, Oxford 2018.

Lange H., Römisches Recht im Mittelalter, München 1997, vol. 1, Glossatoren.

Lange H., Azón (+ ca. 1220) (in:) R. Domingo (ed.) Juristos universales, Madrid 2004, vol. 1, pp. 380-384.

Lange H., Kriechbaum M., Römisches Recht im Mittelalter, München 2007, vol. 2, Kommentatoren.

Longchamps de Bérier F., L'abuso del diritto nell'esperienza del diritto privato romano, Torino 2013.

Maranta R., Conislia sive responsa, Coloniae Agrippinae 1599.

Mazur P, Powolywanie się na nieważność czynności prawnej $z$ naruszeniem zasady venire contra factum proprium niemini licet, „Przegląd Sądowy” 2017, issue 10, pp. 56-66.

Puffendorf S., De jure naturae et gentium, Francofurti ad Moenum 1684.

Riezler E., Venire contra factum proprium. Studien im römischen, englischen und deutschen Civilrecht, Leipzig 1912.

Schacher J. Ch., Disputatio iuridica. De impugnatione facti proprii, 1688.

Singer R., Das Verbot wiedersprüchlichen Verhaltens, München 1993.

Stelmach J., Kodeks argumentacyjny dla prawników, Kraków 2003. Stelmachowski A., Zarys teorii prawa cywilnego, Warszawa 1998. Surdus I. P., Consiliorum sive responsorum, $2^{\text {nd }}$ book, Francofurti ad Moenum 1630.

Tartagnus A., Consiliorum seu responsorum, $2^{\text {nd }}$ book, Venetiis 1610.

Vaccaro F., Juris aphorismi ordine alphabetico digesti, Napoli 1842. Wieacker F., Privatrechtsgeschichte der Neuzeit, Göttingen 1967. Wijffels A., Everardus. A Book on Topics (in:) S. Dauchy, G. Martyn, A. Musson, H. Pihlajmäki, A. Wijffels (eds.) The Formation and Transmission of Western Legal Culture. 150 Books that Made the Law in the Age of Printing, 2016, pp. 65-67. 